International Journal of Business Management, Entrepreneurship and Innovation, Volume 3, Issue 1, 2021, PP 17-35 ISSN 2707-8027

[JCAB

\title{
Generic Strategies and Performance of Pharmaceutical Manufacturing Companies in Nairobi County, Kenya
}

\author{
Grace Wanjiru Ngugi ${ }^{1}$, Esther Gitonga ${ }^{2}$ \\ ${ }^{1}$ Student, Master of Business Administration (Strategic Management) Kenyatta University, Kenya \\ ${ }^{2}$ Lecturer, Department of Business Administration, Kenyatta University, Kenya
}

\begin{abstract}
Pharmaceutical industry has been facing a lot of competition both from the inside and outside the country (importers of raw materials who also manufacture finished product). A report by the Kenya Pharmaceutical Sector Profile in 2018 indicated that imports have been rising sharply and grew by more than 30\% between 2017 and 2018 in other sectors but a decline from the pharmaceutical manufacturing sector which could be attributed to the low-quality pharmaceutical products. The aim of this study was to analyze the generic strategies and performance of pharmaceutical manufacturing companies in Nairobi County, Kenya. The specific objectives were to: assess the effect of cost leadership strategy, differentiation strategy and focus strategy on performance of pharmaceutical companies in Nairobi County, Kenya. The study was informed by Porter's Five Forces Model and Resource Based View theory. The study used descriptive research design. The population of this study was all the 22 pharmaceutical manufacturing companies in Nairobi County. The target population was the managers in the pharmaceutical manufacturing companies. The study was a census of all pharmaceutical manufacturing companies in Nairobi. A structured questionnaire was used for data collection. The questionnaire was pilot tested to determine its validity and reliability. The study used primary data which was gathered from the managers. Data collected was organized in spreadsheets for the purpose of analysis. It was coded and entered in Statistical Package for Social Sciences (SPSS, Version 22.0) for analysis. Correlation and regression analysis were conducted to find the relationship between the independent and dependent variables. The study found that cost leadership strategy, product differentiation strategy and focus strategy positively and significantly influenced performance of pharmaceutical companies in Nairobi County, Kenya. The study concluded that managing the production expenses enhances business performance because of increased profit value. Also, the study concluded that using technology to automate business operations lowers the cost thus increasing profitability. In addition to that, the study concluded that providing high quality products to customers builds customer loyalty which translates to improved performance. Similarly, the research concluded that lowering prices relative to that of competitors attracts more customers leading to increased sales volume. It was recommended that pharmaceutical firms should always aim at lowering the cost of production to reap optimal profits. However, these products should meet the quality demands in the market. It was also recommended that businesses should conduct customer satisfaction surveys to bridge the niche that may be identified. This way, businesses will be able to offer the relevant products and services and gain customer loyalty which eventually leads to increased profitability. In addition, it was recommended that non price competition strategies such as product packaging should be adopted by pharmaceutical firms to increase profitability. Customers would prefer to buy uniquely packaged products as they appear appealing. Future areas of study should focus on other competitive strategies since the three generic strategies that were identified did not account for $100 \%$ of the variation in performance of pharmaceutical firms.
\end{abstract}


International Journal of Business Management, Entrepreneurship and Innovation, Volume 3, Issue 1, 2021, PP 17-35 ISSN 2707-8027

[IJCAB

Key Words: Generic Strategies, Manufacturing Companies, Cost Leadership Strategy, Differentiation Strategy, Focus Strategy

DOI: $10.35942 /$ jbmed.v3i1.157

\section{Cite this Article:}

Ngugi, G., \& Gitonga, E. (2021). Generic Strategies and Performance of Pharmaceutical Manufacturing Companies in Nairobi County, Kenya. International Journal of Business Management, Entrepreneurship and Innovation, 3(1), 17-35. https://doi.org/10.35942/jbmed.v3i1.157

\section{Introduction}

The environment in which today's enterprises operate have been characterized by intense competition calling for the enterprises to become aggressive in securing strategies to enhance their competitiveness to boost their profitability levels (Mutuku, 2014). In a business climate that is characterized by intense competition, rivalry for potential customers, revenue sources and market segments are evident ((McFarlane, 2013). In the current era of rapid technological advancement, there is an increased demand for products and services at a relatively cheaper price. Furthermore, the intense competition among enterprises has resulted to shortening of the product life cycle. Therefore, this has called for aggressiveness in maintaining organizational capabilities to make a competitive hedge against competing parties (Dirisu, Iyiola \& Ibidunni, 2013). It has become a common phenomenon that firms need to have unique approaches to handle operations in the challenging business environment. It is thus agreeable that a competitive advantage puts a firm in a safe position to override its competitors and perform well in the market. In return, business sustainability is achieved. A business organization can hardly manage to take advantage of all the opportunities in the marketplace and are deemed to fail. An organization is termed as competitive if it has put in practice strategies that cannot be imitated by the competitors with ease (Thompson and Strickland, 2010).

According to Nickols (2016), a strategy is a combination of operations undertaken by an enterprise in efforts to get to the future objectives. It is vital for firm to keep on tracking its environment to ensure that they adopt the best strategies which are in line with the forces in the market. Porter (1983) avers that formal or informal competitive strategies exist in each and every business organization. Porter adds that in the future, the ability of a firm to adopt defensive mechanisms influences its survival chances in the future and ability to conquer competitors. As per the sentiment by Scholes, Johnson and Whittington (2002), evidence of a firm having competitive advantages is evidenced by the ability to perform well in the industry. On the other side, Thompson and Strickland (2010) view strategies that are competitive in nature as those that help the particular firm in luring new customers and survive in the pressures of competition thus adding value to customers and improving on performance. On the other hand, Boyne and Walker (2014) contends that the growth of competitive advantage comes with clear comprehension of the prevailing conditions of a competitive environment to determine whether the industry in worth operating in. Lester and Piore, (2015) posit that these strategies that are competitive in nature are an incentive to affirm towards defining the day-to-day business activities in order to identify the appropriate markets to join. Jonsson and Devonish (2009) add that superior performance is usually observed in firms that make use of competitive strategies as opposed to those that do not. Competitive approaches are devised in order to allow an organization to perform well in the face of competition 
International Journal of Business Management, Entrepreneurship and Innovation, Volume 3, Issue 1, 2021, PP 17-35 ISSN 2707-8027

\section{IJCAB}

(Zott, 2013). Porter and Millar (1985) suggested that the major intention behind a firm's adoption of competitive advantage is to improve on business profitability and sustainability.

Barney (2002) introduced the link between competitive advantage and firm performance. The research findings illustrated that the main difference between the high performers remains in the ability to secure competitive approaches to operations and competencies as well. Whilst a lot of corporations start competing on a specific point of distinction, a balance and alignment and renewal of the three components of high performance: the marketplace, attributes and achievement anatomy are nearly always accomplished by the strategic nature of high achievers (Barney, 2002). Porter (1998) says that for a business's potential to surpass its rivals' rests on five essential elements. The very first 4 have set the tactical course for prosperity. We are capable of leveraging patterns in market activity, the capacity to gain and retain disproportionate market dominance, the capacity to absorb high prices, the cautious development and implementation of new items. It needs individuals, functions, and technologies for performance quality.

Firm Performance is the calculation of normal or defined measures of production and environmental quality, the cycle of time, profitability, waste minimization and adherence to regulations (Muchira, 2013). Performance also corresponds to the methods of managing or executing a specific request to succeed in making use of information as opposed to just having it (Sifuna, 2014). The 2 key elements used to calculate productivity are the cutover base and income of firms in the specific industry in which they work. As a more practical indicator of success Kaplan and Norton (2007) developed a Balanced Score Card(BSC). Porter (1980) outlined the three approaches to competitive strategy. These are; striving to be the overall low cost producer, that is, low cost leadership strategy, seeking to differentiate one's product offering from that of its rivals, that is, differentiation strategy and focus on a narrow portion of the market, that is, focus or niche strategy (Arasa \& Githinji, 2014). Cost leadership strategies depend on some fairly unique capabilities of the firm to achieve and sustain their low cost position within the industry of operation (Sifuna, 2014). Cost leadership strategy calls for the firm to be a low cost producer in the industry for a given level of quality. The firm sells its products either at average industry process to earn a profit higher than that of competitors or below the average industry prices to gain market share. The cost leadership strategy usually targets a broad market and firms can acquire cost advantages by improving process efficiencies, gaining unique access to a large source of lower cost materials or avoiding some costs altogether. If the competitors are unable to lower their costs by a similar margin, the firm may be able to sustain a competitive advantage based on cost leadership (Omwoyo, 2016). Onyango (2017) argues that lowering prices without a reduction in operating costs runs the risk of depleting resources and consequently becoming insolvent especially in a fiercely competitive market.

Differentiation strategy refers to a firm striving to create a market unique product for varied customer groups. Competitive strategies dependent on differentiation are designed to appeal to customers with special sensitivity for a particular product attribute (Sifuna, 2014). The differentiation strategy requires a pharmaceutical firm develop a product that offers unique attributes that are valued by customers and are perceived to be better or different from products of competitors. The value added by the uniqueness of the pharmaceutical products may allow the firm to charge a premium price for the product. Since the product has unique attributes, if suppliers increase their prices, the firm may be able to pass on the costs to its customers who cannot find substitute products easily (Ireland, Hoskisson \& Hitt, 2014). Porter (1985) stated that differentiation strategy can be based on technology, design, or innovation. 
International Journal of Business Management, Entrepreneurship and Innovation, Volume 3, Issue 1, 2021, PP 17-35 ISSN 2707-8027

\section{IJCAB}

Focus strategy is a marketing strategy in which an organization concentrates its resources on entering or expanding in a narrow market. It is usually employed where the company knows its segment and has products/services to competitively satisfy its needs (Sifuna, 2014). The focus strategy concentrates on a narrow segment and attempts to achieve either a cost of advantage or a differentiated advantage within that segment (Porter, 1980). It operates on the premise that the needs of the customers in that segment can be served better by focusing entirely on it. A firm using a focus strategy often enjoys a high degree of customer loyalty and this loyalty discourages other firms from competing directly. Firms that succeed in a focus strategy are able to tailor a broad range of product development strengths to a relatively narrow market segment that they know very well (Di Biase, 2015). According to Porter (1985), a firm performs best by choosing one strategy on which to concentrate but others disagree by stating that using a combination of the three strategies may offer a firm the best chance to achieve superior performance (Kinyuira, 2014). However, regardless of the strategy chosen, it must fit with the firm and its goals and objectives in order to succeed (Hahn \&Powers, 2010). According to Statements (2016) consensus forecasts, the pharmaceutical industry is set to grow at $6.3 \%$ per year in compounded annual growth rate reaching $\$ 1.12$ trillion by 2022 . There are two dynamics at play that could affect this optimistic outlook. First, the \$249billion of sales at risk between 2016 and 2022 signals that the pharmaceutical industry has just entered a second patent cliff era where top biologic blockbusters will be challenged by biosimilars.

In the United States of America, healthcare reform and changes in technology, government policy, and consumer expectations are revolutionizing relationships with key stakeholders and impacting operations in unforeseen ways. Globalization is presenting its own set of challenges that span multiple levels of most pharmaceutical organizations from marketing to regulatory. Leslie and Palmisano (2014) believe that companies who succeed in the face of such challenges will do so by placing a renewed emphasis on generic strategies. Moreover, they will adapt effectively in the face of change and uncertainty and will position themselves as a vital partner in the healthcare delivery chain. Therefore, fundamental goal of pharmaceutical manufacturing firm's corporate and functional level strategies is the development of sustainable competitive advantage (Hitt,Ireland \& Hoskisson, 2017). The pharmaceutical industry in Kenya consists of three sectors namely, manufacturers, distributors and retailers who actively support the Ministry of Health and other key players in developing the health sector in Kenya. Companies in the three segments are either large multinational corporations (MNCs), subsidiaries, joint ventures or locally owned corporations. The MNCs manufacture their products locally or import from designated manufacturing sites and supply the drugs to distributors who in turn supply the retail outlets, hospitals, government and non-governmental institutions (Kenya's Pharmaceutical Industry, 2010).

The number of companies engaged in manufacturing and distribution of pharmaceutical products in Kenya continue to expand, driven by the Government's efforts to promote local and foreign investment in the sector. There are about 700 registered wholesale and 1,300 retail dealers in Kenya, manned by registered pharmacists and pharmaceutical technologists. These pharmacies are accorded a $25 \%$ mark-up on retail drugs. Kenya is currently the largest producer of pharmaceutical products in the Common Market for Eastern and Southern Africa (COMESA) region, supplying about 50 per cent of the regions' market (Wilson, 2012). Out of the region's estimated 50 recognized pharmaceutical manufacturers, 22 are based in Kenya. Nairobi hosts the largest contingent of Multinational Pharmaceutical Companies (MNCs) in the region. Major European and American pharmaceutical manufacturing companies are present through locally incorporated 
International Journal of Business Management, Entrepreneurship and Innovation, Volume 3, Issue 1, 2021, PP 17-35 ISSN 2707-8027

[IJCAB

affiliates, technical representative offices and local technical agents (Standard Digital, Jan 25 2018). The industry is regulated by the Kenya Association of Pharmaceutical Industries (KAPI). KAPI was established in the 1960's by a group of R\&D based pharmaceutical manufacturing companies to promote high standards in the industry. The association draws its membership from large MNCs with local affiliates. KAPI's mission is to promote an ethical, innovative and responsible health care industry (Kenya's Pharmaceutical Industry, 2010).

\section{Statement of the Problem}

The pharmaceutical industry in Kenya plays a major role in supporting Kenya's health sector. Kenya is currently the largest producer of pharmaceutical products in the Common Market for Eastern and Southern Africa (COMESA) region, supplying about 50 per cent of the regions' market (Wilson, 2012). Further, Kenya has the largest number of manufacturers (34) with the rest 14 being shared among the remaining East African countries. The industry, therefore, contributes immensely to the country's economy through export and job creation. As such, the facilitation of technology transfer to these countries and the performance of individual companies are of great importance since this is what translates to the overall performance of the industry (Wilson, 2012). Despite its importance, the pharmaceutical industry has been facing a lot of competition both from the inside and outside the country (importers of raw materials who also manufacture finished product). A report by the Kenya Pharmaceutical Sector Profile (2018), indicated that imports have been rising sharply and grew by more than 30\% between 2017 and 2018 in other sectors but a decline from the pharmaceutical manufacturing sector which could be attributed to the low quality pharmaceutical products. The low quality was attributed to low cost of imported products as compared to the locally produced ones. There is therefore need for pharmaceutical manufacturing companies to come up with strategies to enhance their competitive advantage over the importing companies.

Several authors have attempted to analyze competitive strategies and performance of pharmaceutical manufacturing companies. Odhiambo (2013) examined the competitive strategies adopted by Pharmaceutical Firms in Kenya but failed to assess how they affect performance. Munene (2016) explored the strategies adopted by pharmaceutical companies in Kenya to achieve sustainable competitive advantage but also failed to relate with performance. Further, Kamonzo. (2012) surveyed the effect of competitive strategies on performance of veterinary pharmaceutical firms in Nairobi County, Kenya. The study was conducted on veterinary pharmaceutical firms. Oyoolo and Bett (2017) on the other hand researched on the competitive strategies and performance of organizations in the pharmaceutical industry in Kenya but concentrated on one pharmaceutical firm. It is therefore evident that there is limited information about the competitive strategies and how they have affected the performance of pharmaceutical manufacturing firms in Kenya. This study sought to address this gap by analyzing the effect of generic strategies used and performance of pharmaceutical manufacturing companies in Nairobi County, Kenya.

\section{Research Objectives}

The general objective of the study was to analyze the effect of generic strategies used and the performance of pharmaceutical manufacturing companies in Nairobi County, Kenya.

The specific objectives were:

i. To assess the effect of cost leadership strategy on performance of pharmaceutical manufacturing companies in Nairobi County, Kenya 
International Journal of Business Management, Entrepreneurship and Innovation, Volume 3, Issue 1, 2021, PP 17-35 ISSN 2707-8027

[IJCAB

ii. To examine the effect of differentiation strategy on performance of pharmaceutical manufacturing companies in Nairobi County, Kenya

iii. To evaluate the effect of focus strategy on performance of pharmaceutical manufacturing companies in Nairobi County, Kenya

\section{Theoretical Framework}

A theoretical framework is a collection of interrelated concepts. It guides researcher to determine what things to measure, and what statistical relationships to look for (Defee, Randal, Thomas \& Williams, 2010). The underpinning theories in this study were Porter's Five Forces Model, Resource Based View and Configuration Theory.

\subsection{Porter's Five Forces Model}

This theory was proposed by Porter (1998). Porter identifies five forces of competition as fierce rivalry, threat to entry, threat to substitutes, power of suppliers and power of buyers. He upholds that understanding the forces that shape a sectors competition is the basis for developing a strategy. Generic strategies can be effectively correlated to organizational performance by using key strategic practices. Porter posits that if the forces are extreme, no organization earns striking returns on investment and if the forces are benign, most of the companies are profitable. The composition of the five forces varies by industry and that an organization needs a separate strategy for every distinct industry such as the pharmaceutical manufacturing firms. Porter's (1998) generic strategies comprise of low cost, differentiation, focus and combination strategies. These are commonly conventional as a strategic typology for all organizations. Porter (1985) asserts that an organization is mostly concerned with the amount of competition within its industry. He asserts that low cost and differentiation are distinct ends of a continuum and that may for no reason be related to one another has sparked a great deal of theoretical debate and empirical research.

Empirical research using the MIS database by Miller and Dess (2010) suggests that the generic strategy framework could be enhanced by viewing cost, differentiation and focus as three dimensions of strategic positioning other than as three discrete strategies. The idea that pursuing multiple sources of competitive advantage is both feasible and desirable has also been supported by other researchers (White, 2008). Porter's model is an influential tool for methodically diagnosing the main competitive pressures in a market and assessing how strong and significant each one is. Kitoto (2005) observed that a correct analysis of the five forces will assist a firm choose one of the generic strategies that will successfully enable the organization to compete profitably in an industry. Managers in the pharmaceutical manufacturing firms therefore can only develop and choose winning strategies by first identifying the competitive pressures that exists, measuring the virtual strength of each and gaining a profound understanding of the sectors whole competitive structure. Porter's model approach allows for the determination of the attractiveness of the industry. With the knowledge about intensity and power of competitive forces, pharmaceutical manufacturing firms can then develop options to influence them in a way that improves their own competitive position. To survive, the firms must adapt their strategies to suit the dynamic market place. The winning strategy selected can change the impact of competitive forces on the firm. The aim is to decrease the power of competitive forces. Although numerous companies pursuing cost and differentiation concurrently may become trapped in the middle, there is patent evidence to suggest that at least some companies have been triumphant in achieving higher economic performance by pursuing both advantages (Bresnahan \& Reiss, 2010). This theory is deemed relevant in this study as it explains the role played by the competitive strategies 
International Journal of Business Management, Entrepreneurship and Innovation, Volume 3, Issue 1, 2021, PP 17-35 ISSN 2707-8027

iJCAB

in ensuring that firms thrive in the face of the uncertain business environment and also remain sustainable.

\subsection{Resource Based View}

This theory was proposed by Wernerfelt (1984). The theory suggests that the evaluation of companies in terms of their disposable resources could lead to different insights from traditional perspectives that view competitive advantage as a rather external paradigm and argue that the alignment of a firm to its external environment is the main determining factor for a firm's profitability. Barney (1991) developed a framework for the identification of the properties of firm resources needed for the generation of a sustainable competitive advantage. The properties include whether resources are valuable, rare among a firm's current and potential competitors, imitable and non-substitutable. If resources have these characteristics they can be seen as strategic assets. Subsequently, this notion has been adopted by many researchers (Amit \&Schoemaker, 2010; Peteraf, 2010) and expanded to include the properties of resource durability, non-tradability, and idiosyncratic nature of resources. Grant developed a practical framework for a resource-based approach to strategy consisting of the identification of resources and capabilities, their potential for achieving competitive advantage with appropriable return, the strategy selection and the consequent identification of resource gaps. Differentiation supports and sustains competitive advantage, but conformity to institutional pressures provides legitimacy, resources, and competitive advantage. In contexts where institutional and competitive pressures exert strong influences, the strategic decisions of managers result both in conformity to institutional pressures, which leads to isomorphism and legitimacy, and in differentiation, which, following the resourcebased view of the firm, can increase the possibility of creating a competitive advantage through heterogeneity in resources and capabilities. Although both alternatives have an effect on performance of pharmaceutical manufacturing firms and the creation and maintenance of dominant market positions, little attention has been paid to the analysis of the effects of conformity on performance of pharmaceutical manufacturing firms and competitive advantage.

This theory is deemed relevant in this study as it describes the role of differentiation strategy in building up techniques the pharmaceutical manufacturing firms in Kenya may focus on, in order to have the capacity to make an incentive for its clients. This is because differentiation tends to reduce rivalry, lower cost of production, increasing the possibility of building competitive advantages, whereas conformity improves the social support of stakeholders and therefore the legitimacy of the firm. Differentiation reduces competitiveness and the fight for scarce resources, thereby improving performance of organizations; but on the other hand, conformity makes all organizations similar and, therefore, the competitive pressures are stronger. Differentiation will create benefits and dominant positions that will last until competitors imitate a firm's key resources, and will be restored through the creation of new opportunities that result in a new competitive advantage and new entry barriers (Ogbonna \& Harris, 2003). The new lines of institutional thinking answer this question and establish a point of connection with the resources-based view.

\subsection{Configuration Theory}

The configuration school which perceive strategy formulation as a transformation process was developed in the 1960s and 70s. Major contributors to configuration school are Chandler (1962), Mintzberg and Miles \& Snow (1978). The concept of configuration theory postulates that the performance of an organization depends on the fit of environment and organizational design. The basic assumption behind the theory is that the best performance can be achieved when organization 
International Journal of Business Management, Entrepreneurship and Innovation, Volume 3, Issue 1, 2021, PP 17-35 ISSN 2707-8027

\section{IJCAB}

structure matches external contingency factor. Only those organizations that align their operation with the current environment achieve maximum output. The general model implicit in configuration theory assumes that for organizations to be effective there must be an appropriate fit between structure, strategy and environmental context (Fincham \& Rhodes, 2005).

Empirical studies regarding configuration have also consistently found evidence that the fit among organizational characteristics is an important predictor of firm performance (Slater \& Olson, 2000). According to Gao et al. (2007), any firm's external environment is exogenous, so the firm must adjust its strategy according to the environmental constraints. As such, there are no universally optimal strategic choices for all businesses. In the context of this study, configuration theory brings out the link between competitive strategies and the competitive intensity as an aspect of external environmental which may influence pharmaceutical manufacturing firms in Kenya on the choice of competitive strategies based on the changes in the environment as well as the basis of explaining the necessity to have a fit between competitive strategies, competitive intensity and firm performance. However, pharmaceutical manufacturing firms in Kenya seem to adopt competitive strategies without due consideration to the environmental factor hence realizing negative effect on their performance. In the context of this study, configuration theory brings out the link between competitive strategies and the competitive intensity as an aspect of external environmental which may influence pharmaceutical manufacturing firms performance based on the changes in the environment as well as the basis of explaining the necessity to have a fit between competitive strategies, competitive intensity and firm performance. However, manufacturing firms in Kenya seem to adopt competitive strategies without due consideration to the environmental factor hence realizing negative effect on their performance (Atikiya, 2015).

\section{Empirical Review}

This section entailed the review of past studies to identify areas of divergence or convergence with the current study. Chepchirchir, Omillo and Munyua (2018) studied the effect of cost leadership strategy on organizational performance of logistics firms at Jomo Kenyatta international airport, Kenya. The study looked at the degree to which application of cost leadership strategies resulted to performance improvement. This research was guided by Porters five forces theory. The study was informed by explanatory research design. It targeted a population of 151 respondents and a sample size of 110 top and middle level managers forming the study population. The study data came from 10 logistics firms with active websites operating at JKIA Nairobi. The respondents identified were selected using simple random sampling technique. A questionnaire based on the variables of the study was used to collect data from respondents. Analysis of data involved use of descriptive and inferential statistics. It was found out that cost leadership had a significant positive effect $(\mathrm{p}<0.05)$ on logistics firms performance. It was found out that as a result of utilizing this approach, there was increased sales volume and profits. Further, there was reduction of costs associated with operations that resulted to increased profit margin.

Omwoyo (2016) conducted a study on the effects of generic strategies on the competitive advantage of firms in Kenya's airline industry. One of the study objectives was to establish how cost leadership strategy affect competitive advantage of selected airline firms. The study embraced a descriptive research method in analyzing, interpreting, and presenting data. The study used questionnaires to get data from respondents. The study focused on 100 management employees from Kenya Airways, Fly 540 and Fly-SAX. The study used census approach on the targeted population. The study found that companies in airline industry strive to supply a standard of high 
International Journal of Business Management, Entrepreneurship and Innovation, Volume 3, Issue 1, 2021, PP 17-35 ISSN 2707-8027

\section{IJCAB}

volume services at the most competitive prices to customers. Cost leadership strategy makes the companies to benchmark themselves against competing firms to access their relative costs. Chengeta (2014) did a study on the effect of cost leadership strategies on company performance with focus on Multimedia Saatchi \& Saatchi. The main objectives of this research were to find out the effect of vertical integration on market share, to determine the effects of restructuring on company profitability, to evaluate whether outsourcing from cheapest supplier managed to reduce company cost. The researcher used descriptive research to obtain insights and clarification on the research understudy and the researcher used interviews, questionnaires to obtaining raw data from the respondents on the issues of concern. The results drawn from the research indicated that vertical integration is important to the organization as it improves efficiency, also clientele base and market share at large and that restructuring results in reduction in company cost and improving financial performance. The findings also indicated that outsourcing from cheapest supplier yield positive results in terms of reducing company cost and the results also showed that sourcing from cheapest supplier doesn't necessarily mean low quality service. Olson and Swanson (2010) did a research on Market Forces and Changes in the Plant Input Supply Industry. The study found that as concerns suppliers, the low-cost producer is more insulated than competitors from powerful suppliers if greater internal efficiency is the primary source of its cost advantage. As concerns potential entrants, the low-cost producer can use price-cutting to make it harder for a new rival to win customers; the pricing power of the low-cost producer acts as a barrier for a new entrant.

Nuru (2015) studied the influence of differentiation strategy on performance of water bottling companies in Mombasa County, Kenya. The specific objectives of the study were to determine the influence of differentiation strategy on performance of water bottling companies in Mombasa County and investigate the extent to which water bottling companies in Mombasa county use differentiation strategy. A cross-sectional explanatory design will be used. The target population in this study was the registered water bottling companies in Mombasa County, Kenya. Both primary and secondary data was used. The findings of the study showed that there is a positive relationship between differentiation strategy and firm performance. Product differentiation strategy contributes more to the performance of water bottling companies than service differentiation strategy. Demba (2018) studied the effect of differentiation strategy on performance by selected car rental business, a case of Nairobi city county, Kenya. This study was a crosssectional descriptive study design where purposive sampling technique was used to select fiftteen (15) car rental business in Nairobi City County. Structured questionnaire was used to collect primary data. The findings of the study revealed that differentiation strategy was statistically insignificant at $\mathrm{P}$ value greater than 0.05 by Chi-square and analysis of variance thereby accepting the null hypothesis that differentiation strategy had no effect on performance of car hire business in Nairobi City County. Correlation analysis revealed a negative relationship between indicators for performance improvement and differentiation strategy used. In addition, correlation analysis revealed that there was a positive relationship between the extent of performance differentiation strategy used. Multiple logistic regression analysis showed that there was no significant impact of differentiation strategy on performance. In conclusion, differentiation strategy adopted by the selected car rental business in Nairobi City County had no effect on their performance.

Adimo (2018) sought to establish the relationship between product differentiation strategies and organizational performance in Sameer Africa Kenya limited. The study targeted 112 employees of Sameer Africa (K) Limited, comprising senior management, HODs and junior staff and 90 dealers based in Nairobi. A sample of 134 respondents was selected using stratified random 
International Journal of Business Management, Entrepreneurship and Innovation, Volume 3, Issue 1, 2021, PP 17-35 ISSN 2707-8027

\section{IJCAB}

sampling and simple random sampling techniques. The study was guided by Strategic Balance Theory. Primary data was collected through self-administered questionnaires. The study found that product differentiation had a positive relationship with organizational performance. The study also found that integrating product differentiation strategies through specific product attributes relevant to competitors and variety of products to match the need of various customers resulted to improved performance. Shafiwu and Mohammed (2013) investigated the effect of product differentiation on profitability in the petroleum industry in Ghana. The research sought to establish the relationship between differentiation and profitability in the petroleum industry and whether or not people patronized Effimax products. The research employed a correlation research design. It targeted15 government owned and 14 privately owned oil marketing companies in Ghana. Cluster sampling technique was used to select one company out of the population. The study concluded that despite the fact that the petroleum industry is not seen to have differentiated products relative to other industries, it does not mean that the act of differentiation in itself is not a profitable strategy suitable to the industry. Rather, there may be other factors responsible for the less adoption. Shafiwu and Mohammed (2013) recommend the need to create awareness on the products

Dirisu, Oluwule and Ibidunni (2013) studied product differentiation as a tool of competitive advantage and optimal organizational performance focusing on Unilever Nigeria. The study focused on how competitive advantage can be achieved through product differentiation strategy and, ultimately, on how it influences the performance of the organization in the manufacturing company. Survey research was adopted for the research because of the nature of the respondents. This entailed the administering of questionnaires to the chosen sample. The population of the respondents was rather large, made up of all customers/consumers of the products of Unilever Nigeria Plc. The analysis carried out proved the existence of a positive significant relationship between product differentiation and the sales growth of an organization. Kinyuira (2014) did a research on the effects of Porter's Generic Competitive Strategies on the performance of savings and credit cooperatives in Murang'a County, Kenya. The study found significant positive effects of cost leadership, differentiation and focus strategies on performance of Saccos and concluded that Saccos that pursue generic strategies can achieve superior performance compared to those that do not.

Kamar (2014) sought to investigate the effects of competitive strategies on the performance of liquefied petroleum gas companies: a survey of Eldoret town, Kenya. The specific objectives included: to investigate the effects cost leadership strategy, differentiation strategy, focus strategy, and pricing strategy on performance. Performance was indicated by market share sales volume and cost minimization. The studies used a survey design. It was found that cost leadership influences the performance of LPGCs performance. The gain cost leadership through minimizing procurement cost minimizing, operational costs, conducting cost of its labor, service costing and evaluation of promotion costs. It was also found that differentiation strategy leads to high levels of performance. The products of LPGCs are differentiated through product differentiation, different prices, production process, promotion strategies and different designs. Most importantly, the study found that focus strategy influences the competitive advantage of most LPGCs leading to high levels of performance. Most LPGCs hence adopted focus strategy in terms of focusing on specific products, focusing of its market deduction its customers, niche marketing, and clear focus of its product lines when the LPGCs focus on specific products they become specialized in those products and gain a competitive edge of quality and efficiency pricing strategy influences the performance of LPGCs. 
International Journal of Business Management, Entrepreneurship and Innovation, Volume 3, Issue 1, 2021, PP 17-35 ISSN 2707-8027

\section{[IJCAB}

Muia (2017) did a study on effect of Competitive Strategies on the Performance of Insurance Companies in Kenya. One of his objectives was to determine the effect of focus strategy on performance of insurance companies in Kenya. The study employed a descriptive research design and this was appropriate for this research to ascertain the prevailing conditions of facts in a sample. The target population consisted of all strategic planning departments in the 47 insurance companies in Kenya listed under the membership of Association of Kenya insurance (AKI). A purposive sampling technique was used to select a sample of three employees from strategic planning department in each insurance company resulting in 141 respondents. The study established that majority of insurance firms serve specific geographical market and emphasize on marketing specialty product. The findings also established that many deal with broad product serving wider market while majority constantly target a specific market. A correlation analysis between focus strategy and performance was strong and positive and the regression coefficients showed a positive and significant relationship between focus strategy and insurance performance.

\section{Conceptual Framework}

\section{Cost Leadership Strategy}

- Lowering costs of production

- Lowering marketing costs

- Offering discounts

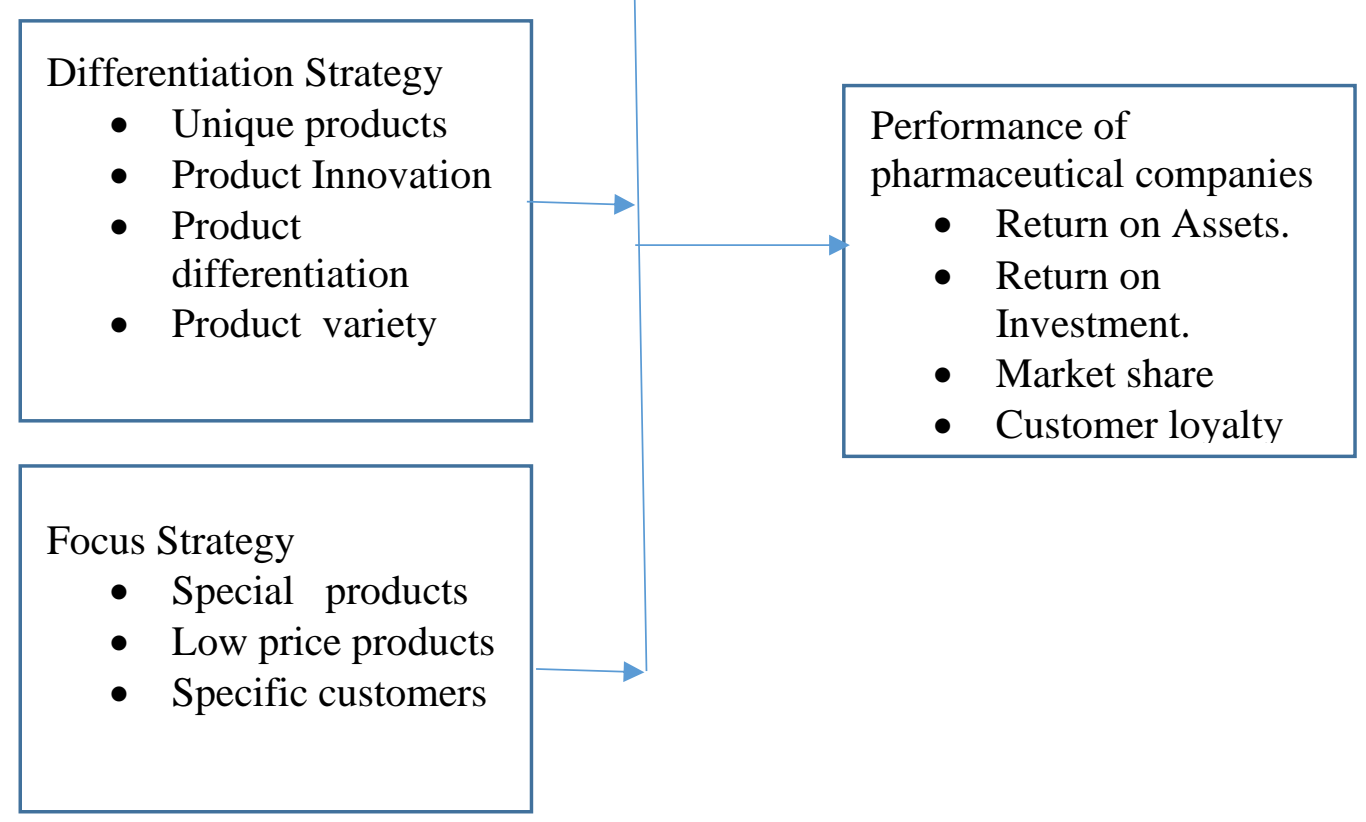

Figure 1: Conceptual Framework

\section{Source, Reviewed Literature (2019)}

The independent variables in this study were cost leadership strategies, product differentiation strategies and focus strategies. The independent variable in the study was performance of pharmaceutical manufacturing companies. A low-cost position protects the firm against effective 
International Journal of Business Management, Entrepreneurship and Innovation, Volume 3, Issue 1, 2021, PP 17-35 ISSN 2707-8027

\section{IJCAB}

purchasers since purchasers can apply control just to drive down costs to the level of the following most proficient contender and subsequently enhance execution of organizations. Differentiation strategy of a firm looks to be one of a kind in its industry along a few measurements that are generally esteemed by purchasers which thus upgrade intensity and execution of firms. Focus strategy depend on embracing a tight focused extension inside an industry. It goes for developing market share through working in a specialty advertise or in business sectors either not alluring to, or ignored by, bigger contenders. This thus improve performance of firms.

\section{Research Methodology}

A research design is a framework used to collect data and analyze with the aim of answering the research questions (Chilibasi, 2012). Cooper and Schindler (2011) defined research design as the plan and structure conceived to obtain answers to research questions. Research design is glue that holds all the elements of research together (Shala, 2017). The study will adopt a descriptive research design. According to Cooper \& Schindler (2009), the objective of the descriptive study is to describe phenomena as it exists at present. A descriptive design was appropriate for this study as it enabled the researcher to investigate the target population and establish the factors under investigation. Other similar studies have also used descriptive research design (Terfa, Ereso, Kebede, Rajendran \& Nedelea, 2017). There are 22 registered member pharmaceutical manufacturing firms distributed across Nairobi County, Kenya (See Appendix III). The target population of the study was the managers in the manufacturing pharmaceutical companies in Nairobi. This comprised of the CEO, general manager, and marketing manager. The managers were selected as they are the ones involved in day-to-day strategic management activities of the firms. The study was a census of all the top managers of manufacturing pharmaceutical companies in Nairobi. According to Drechsler and Reiter (2010), census technique is useful when the target population is relatively small. In the current study, the census technique was applied since the target population was 66 managers.

Primary data was collected though a questionnaire. The questionnaire had closed ended questions. The closed ended questions enabled collection of quantitative data. The questionnaire was divided into five sections. Authorization to collect data from the selected organizations was acquired from the university. Consent will be sought through use of an introductory letter for data collection which will be obtained from Kenyatta University. The researcher also obtained authorization letter from Kenyatta University and National Commission for Science Technology and Innovation to collect the data. After permission is granted, appointments will be made with the respective respondents. The questionnaires will be administered with the help of research assistants through the drop and pick later method. The data collected through the questionnaire was edited, coded, entered into SPSS which also aids in data analysis. The data was analyzed using descriptive and inferential statistics. The descriptive statistics included frequencies, means and standard deviations. The inferential statistics included correlation annalysis and a regression model to establish the relationship between variables. The analyzed quantitative data was presented using tables and figures.

\section{Data Analysis Results}

Inferential analysis was conducted to generate correlation results, model of fitness and analysis of the variance and regression coefficients. 
International Journal of Business Management, Entrepreneurship and Innovation, Volume 3, Issue 1, 2021, PP 17-35 ISSN 2707-8027

[JCAB

\subsection{Correlation Analysis}

Correlation analysis was conducted to find out the relationship between the independent variables and the dependent variable.

Table 1 Correlation Analysis

\begin{tabular}{|c|c|c|c|c|c|}
\hline & & Performance & $\begin{array}{l}\text { Cost } \\
\text { Leadership }\end{array}$ & Differentiation & Focus \\
\hline \multirow{3}{*}{ performance } & Pearson & \multirow{3}{*}{\multicolumn{2}{|c|}{1}} & & \\
\hline & Correlation & & & & \\
\hline & Sig. (2-tailed) & & & & \\
\hline $\operatorname{cost}$ & Pearson & & & & \\
\hline \multirow[t]{3}{*}{ leadership } & Correlation & $.592 * *$ & 1 & & \\
\hline & Sig. (2-tailed) & 0.001 & & & \\
\hline & Pearson & & & & \\
\hline \multirow[t]{3}{*}{ differentiation } & Correlation & $.651^{* *}$ & -0.14 & 1 & \\
\hline & Sig. (2-tailed) & 0.000 & 0.264 & & \\
\hline & Pearson & & & & \\
\hline \multirow[t]{2}{*}{ focus } & Correlation & $.556^{* *}$ & 0.174 & 0.115 & 1 \\
\hline & Sig. (2-tailed) & 0.003 & 0.163 & 0.357 & \\
\hline
\end{tabular}

** Correlation is significant at the 0.01 level (2-tailed).

\section{Source: Survey Data (2019)}

The findings showed that cost leadership strategy and firm performance are positively and significantly related( $\mathrm{r}=0.592, \mathrm{p}=0.001)$. This finding supports that of Chepchirchir, Omillo and Munyua (2018) as a result of utilizing this approach, there was increased firm sales volume and profits. Further, there was reduction of costs associated with operations that resulted to increased profit margin. The findings also showed a strong positive and significant relationship between differentiation strategy and firm performance $(\mathrm{r}=0.651, \mathrm{p}=0.000)$. This is in line with findings of Nuru (2015) whose findings that there is a positive relationship between differentiation strategy and firm performance. However, it disagrees with that of Demba (2018) who found that differentiation strategy adopted by the selected car rental business in Nairobi City County had no effect on their performance. In addition, there was a strong positive and significant relationship between focus strategy and firm performance $(\mathrm{r}=0.556, \mathrm{p}=0.003)$. This supports findings by Muia (2017) whose finding showed that a correlation analysis between focus strategy and performance was strong and positive and the regression coefficients showed a positive and significant relationship between focus strategy and insurance performance.

\subsection{Regression Analysis}

Regression analysis was done to determine the effect of the independent variables on the dependent variable. The results in Table 2 presented the fitness of model of regression model used in explaining the study phenomena.

Table 2 Model Fitness

Indicator Coefficient


International Journal of Business Management, Entrepreneurship and Innovation, Volume 3, Issue 1, 2021, PP 17-35 ISSN 2707-8027

iJCAB

\begin{tabular}{lc} 
R & 0.928 \\
R Square & 0.863 \\
Adjusted R Square & 0.854 \\
Std. Error of the Estimate & 0.08986 \\
\hline
\end{tabular}

\section{Source: Survey Data (2019)}

Cost leadership strategy, differentiation strategy and focus strategy were found to be satisfactory variables in explaining firm performance in pharmaceutical firms. This finding agrees with that of Kinyuira (2014) who found significant positive effects of cost leadership, differentiation and focus strategies on performance of SACCOs. This was supported by coefficient of determination also known as the R square of $86.3 \%$. This meant that cost leadership strategy, differentiation strategy and focus strategy explain $86.3 \%$ of the variations in the dependent variable which was performance. The results further meant that the model applied to link the relationship of the variables was satisfactory. In statistics significance testing, the p-value indicates the level of relation of the independent variable to the dependent variable. If the significance number found is less than the critical value also known as the probability value (p) which is statistically set at 0.05 , then the conclusion would be that the model is significant in explaining the relationship; else the model would be regarded as non-significant. Table 3 provided the results on the analysis of the variance (ANOVA).

Table 3 ANOVA

\begin{tabular}{llrrrrr}
\hline Model & & Sum of Squares & df & Mean Square & F & Sig. \\
\hline \multirow{3}{*}{1} & Regression & 9.167 & 3 & 3.056 & 17.831 & $.000^{\mathrm{b}}$ \\
& Residual & 10.624 & 62 & .171 & & \\
& Total & 19.791 & 65 & & & \\
\hline
\end{tabular}

Source: Survey Data (2019)

Regression analysis indicated that the model was statistically significant. Further, the results imply that the independent variables were a good predictor of pharmaceutical firms' performance. This was supported by a calculated F statistic of 17.387 which was greater than the critical F statistic of 12.156. The reported $\mathrm{p}$ value (0.000) was also less than the conventional probability of 0.05 significance level. Therefore, all the generic strategies have a significant influence on the performance of pharmaceutical firms was rejected.

Table 4: Regression of Coefficients

\begin{tabular}{lcccc}
\hline & $\boldsymbol{\beta}$ & Std. Error & $\mathbf{t}$ & Sig. \\
\hline (Constant) & 0.507 & 0.556 & 0.911 & 0.016 \\
Cost leadership & 0.452 & 0.103 & 4.381 & 0.000 \\
Differentiation Strategy & 0.468 & 0.092 & 5.09 & 0.001 \\
Focus Strategy & 0.234 & 0.098 & 2.382 & 0.02 \\
\hline
\end{tabular}

Source: Survey Data (2019)

Regression analysis showed that there is a positive and significant relationship between Cost Leadership and performance $(\beta=0.452, \mathrm{p}=0.000)$. This implies that a unit increase in cost leadership would lead to improvement in firm performance by 0.452 units. The analysis also indicated that that there is a positive and significant relationship between product differentiation and firm performance $(\beta=0.468, \mathrm{p}=0.000)$. Similarly, this implies that a unit increase in product differentiation would lead to improvement in firm performance by 0.468 units. Further, the 
International Journal of Business Management, Entrepreneurship and Innovation, Volume 3, Issue 1, 2021, PP 17-35 ISSN 2707-8027

\section{IJCAB}

regression results revealed that there is a positive and significant relationship between focus strategy and firm performance $(\beta=0.234, \mathrm{p}=0.000)$. This means that a unit increase in focus strategy would lead to improvement in firm performance by 0.234 units. Thus, the optimal model for the study is; $Y=0.507+0.452$ Cost leadership +0.468 Product Differentiation +0.234 Focus strategy.

\section{Conclusions}

It was concluded that investment in state-of-the-art equipment and control of organizational overheads leads to an increase on firm's profitability. Based on the study findings, the study further concluded that avoidance of marginal customer accounts and cost minimization in research and development results to improvement in firm profitability. Additionally, the study concluded that cost minimization in sales and advertising leads to increase Return on Assets. Based on the findings, it was concluded that development of unique products and Building perceptions of exclusivity of organizational products results to firm profitability as well as increased market share. It was also concluded that developing high quality products and offering after sale support services enhances customer loyalty and increased market share. Additionally, it was concluded that using a different marketing approach compared to the competition increases the sales volume and firm's Return on Assets. Based on the findings, it was concluded that reducing the prices of product when venturing into a new market leads to increased sales and improvement in the market share. The study further concluded that dealing with market with special needs leads to increased sales volume and customer loyalty. It was further concluded that adjusting price to attract new customers and focusing on markets overlooked by competitors results to increased firm profits and increased market share.

\section{Recommendations}

Based on the findings, it is recommended that firms should Investment in state-of-the-art equipment and Control of organizational overheads to increase on their profitability. The study also recommends that the pharmaceutical firms' management should reduce marginal customer accounts and minimize the research and development expenses to make more profit margins. The study further recommends that pharmaceutical firms should minimize the sales and advertising costs to enhance more Return on Assets. It was recommended that businesses should conduct customer satisfaction surveys in order to bridge the niche that may be identified. This way, businesses will be able to offer the relevant products and services and gain customer loyalty which eventually leads to increased profitability. In addition, it was recommended that non price competition strategies such as product packaging should be adopted by pharmaceutical firms to increase Return on Assets. Customers would prefer to buy uniquely packaged products as they appear appealing. It was recommended that the managers of the pharmaceutical firms should strategically reduce the prices of products when venturing into a new market to reap increased sales and improvement in the market share. The study further recommended that firms should consider dealing with market with special needs inorder to achieve increased sales volume and customer loyalty.

\section{REFERENCES}

Atikiya, R. (2015). Effect of competitive strategies on the performance of manufacturing firms in Kenya. Unpublished thesis Jomo Kenyatta University of Agriculture and Technology Barney, J. B. (2002). Gaining and sustaining competitive advantage. New Jersey: Prentice Hall. 
International Journal of Business Management, Entrepreneurship and Innovation, Volume 3, Issue 1, 2021, PP 17-35 ISSN 2707-8027

\section{[IJCAB}

Barney, J. B. (2002). Strategic management: From informed conversation to academic discipline. Academy of Management Perspectives, 16(2), 53-57.

Boyne, G. A., \& Walker, R. M. (2014). Strategy content and public service organizations. Journal of public administration research and theory, 14(2), 231-252.

Bryman, A., \& Bell, E. (2011). Reliability and validity in qualitative research.

Burns, N., \& Grove, S. K. (2010). Understanding Nursing Research-eBook: Building an EvidenceBased Practice. Elsevier Health Sciences.

Chandler, G.N., \& Hanks, S.H. (1994). Market attractiveness, resource-based capabilities, venture strategies and venture performance. Journal of Business Venturing, 9 (4), 331-349.

Chengeta, M. (2014). The effect of cost leadership strategies on company performance: a case of Multimedia Saatchi \& Saatchi.

Chepchirchir, A. B., Omillo, F., \& Munyua, J. (2018). Effect Of Cost Leadership Strategy On Organizational Performance Of Logistics Firms At Jomo Kenyatta International Airport, Kenya. European Journal of Management and Marketing Studies.

Cooper, D.R. \&Schindler, P.S. (11th Ed).(2011).Business Research Methods. New York: McGraw-Hill/Irwin Publishers.

Defee, C., Williams, B., Randall, W. S., \& Thomas, R. (2010). An inventory of theory in logistics and SCM research. The International Journal of Logistics Management, 21(3), 404-489.

Demba G. I. (2018). Generic Strategies and performance of selected car rental business in Nairobi City County. Journal of Business Management, 14(4), 23-27.

Di Biase, S. A. (2015). Applied Innovation: A Handbook. Premier Insights LLC.

Dirisu, I., Oluwole, I., \& Ibidunni, O. (2013). Product Differentiation: A Tool of Competitive Advantage and Optimal Organizational Performance (A Study of Unilever Nigeria Plc).European Scientific Journal, 9(34

Dirisu, I., Oluwole, I., \& Ibidunni, O. (2013). Product Differentiation: A Tool of Competitive Advantage and Optimal Organizational Performance (A Study of Unilever Nigeria Plc).European Scientific Journal, 9(34

Dirisu, J. I., Iyiola, O., \& Ibidunni, O. S. (2013). Product differentiation: A tool of competitive advantage and optimal organizational performance (A study of Unilever Nigeria PLC). European Scientific Journal, ESJ, 9(34).

Dobre, O. I. (2013). Employee motivation and organizational performance. Review of applied socio-economic research, 5(1).

Fincham, R., \& Rhodes, P. (2005). Principles of organizational behaviour (5th ed.). New York: Oxtford University Press

Gao, G.Y., Zhou, K.Z., \& Yim, C.K.B. (2007). On what should firms focus in transitional economies? A study of the contigent value of strategic orientations in China. International Journal of Research in Marketing. 24, 3- 15.

Gereffi, G. (2017). The pharmaceutical industry and dependency in the Third World. Princeton University Press.

Hahn, W., \& Powers, T. L. (2010). Strategic plan quality, implementation capability, and firm performance. Academy of Strategic Management Journal, 9(1), 63.

Hitt, M. A., Ireland, R. D., Sirmon, D. G., \& Trahms, C. A. (2017). Strategic entrepreneurship: creating value for individuals, organizations, and society. The Academy of Management Perspectives, 25(2), 57-75

Ireland, R. D., Hoskisson, R. E., \& Hitt, M. A. (2014). Strategic management: concepts and cases: competitiveness and globalization. Boston: South-Western College Publishing, 201. 
International Journal of Business Management, Entrepreneurship and Innovation, Volume 3, Issue 1, 2021, PP 17-35 ISSN 2707-8027

[IJCAB

Jönsson, C., \& Devonish, D. (2009). An exploratory study of competitive strategies among hotels in a small developing Caribbean state. International Journal of Contemporary Hospitality Management, 21(4), 491-500.

Kamar, I. K. (2014). Effects Of Competitive Strategies On The Performance Of Liquified Petroleium Gas Companies: A Survey Of Eldoret Town, Kenya (Doctoral dissertation, Kisii University).

Kamonzo, K. J. (2012). A survey of the effects of competitive strategies on performance of veterinary pharmaceutical firms in Nairobi County, Kenya (Doctoral dissertation).

Kaplan, R. S., \& Norton, D. P. (2007). Balanced scorecard. In Das Summa Summarum des Management (pp. 137-148). Gabler.

Kariithi, J. N., \& Kihara, A. (2017). Factors affecting performance of manufacturing firms in Kenya: A case of pharmaceutical firms in Nairobi County. Strategic Journal of Business \& Change Management, 4 (2).

Kim, P. B., Kim, S., Kim, S. S., \& Kim, J. (2017). Organizational drivers and outcomes of casino employees' work adaptability. Journal of Hospitality Marketing \& Management, 26(3), 276-296.

Kinyuira, D. (2014). Effects of Porter's Generic Competitive Strategies on the performance of savings and credit cooperatives (Saccos) in Murang'a County, Kenya. IOSR Journal of Business and Management, 16(6).

Kinyuira, D. (2014). Effects of Porter's Generic Competitive Strategies on the performance of savings and credit cooperatives (Saccos) in Murang'a County, Kenya. IOSR Journal of Business and Management, 16(6).

Kombo \& Tromp. (2009).Techniques of Social Research. New Delhi: New Age Publications (Academic).

Kothari, C. R. (2004). Research methodology: Methods and techniques. New Age International.

Leslie, J. B., \& Palmisano, K. (2014). The Leadership Challenge in the Pharmaceutical Sector. Center for Creative Leadership

Lester, R. K., \& Piore, M. J. (2015). Innovation-The missing dimension. Harvard University Press.

McFarlane, D. A. (2013). The strategic importance of customer value. Atlantic Marketing Journal, 2(1), 5 .

Mile, R. E., \& Snow, C.C. (1978). Organizational strategy, structure and process. New York, NY: McGraw-hill.

Miller, D. \& Dess, P.H. (2010). Organizations: A Quantum View, Englewood Cliffs: Prentice Hall.

Muchira, W. N. (2013). Relationship between strategy implementation and performance in commercial banks in Kenya. Unpublished MBA project, School of Business University of Nairobi.

Mugenda, A. G. (2008). Social science research: Theory and principles. Nairobi: Applied.

Muia, F. (2017). Effect of Competitive Strategies on the Performance of Insurance Companies in Kenya (Doctoral dissertation, United States International University-Africa).

Munene, W. (2016). An exploration of strategies adopted by pharmaceutical manufacturing companies in Kenya to achieve sustainable competitive advantage (Doctoral dissertation, Strathmore University).

Mutuku, J. M. (2014). Strategic responses to dynamic business environment in Kenya by Old Mutual Kenya Limited. Unpublished MBA Project. Nairobi: University of Nairobi. 
International Journal of Business Management, Entrepreneurship and Innovation, Volume 3, Issue 1, 2021, PP 17-35 ISSN 2707-8027

\section{IJCAB}

Nderitu, P. M. (2015). Relationship between competitive strategies and performance: a case study of Bamburi Cement Limited (Doctoral dissertation, School of Business, University of Nairobi).

Nickols, F. (2016). Strategy, strategic management, strategic planning and strategic thinking. Management Journal, 1(1), 4-7.

Nuru, T. J. (2015). The influence of differentiation strategy on performance of water bottling companies in Mombasa county, Kenya (Doctoral dissertation, School Of Business, University Of Nairobi).

Odeny, O. E. (2018). Strategic planning and performance of pharmaceutical manufacturing firms in Kenya (Doctoral dissertation, Doctoral Dissertation), School of Business, University of Nairobi).

Odhiambo, A. (2013). Competitive Strategies Adopted by Pharmaceutical manufacturing Firms in Kenya. Unpublished doctoral dissertation University of Nairobi.

Ogbonna, E. \& Harris, L. (2003). Innovative organizational structures and performance: a case study of structural transformation to groovy community centers, Journal of Organizational Change Management, Vol. 16(5), 512-34.

Olson, K. R., \& Swanson, M. (2010). Market Forces and Changes in the Plant Input Supply Industry. Choices, 25(4), 6-11

Omwoyo, R. M. (2016). Effects of Generic Strategies on the Competitive Advantage of Firms in Kenya's Airline Industry: A Survey of Selected Airlines (Doctoral dissertation, United States International University-Africa).

Omwoyo, R. M. (2016). Effects of Generic Strategies on the Competitive Advantage of Firms in Kenya's Airline Industry: A Survey of Selected Airlines (Doctoral dissertation, United States International University-Africa).

Onyango, J. J. (2017). Influence of Cost Leadership, Differentiation and Focus Strategies on Firm Competiveness: The Case of BOC Kenya Limited (Doctoral dissertation, United States International University-Africa).

Orodho, A. J. (2010). Essentials of educational and social science research methods: Qualitative and quantitative approaches.

Oyoolo, J. D., \& Bett, S. (2017). Competitive strategies and performance of organizations in the pharmaceutical manufacturing industry: Case of Pharma Specialities Limited Nairobi, Kenya. International Academic Journal of Human Resource and Business Administration, 2(4), 156-173.

Pearce, J. A., \& Robinson, R. B. (2007). Strategic Management: Strategy Formulation and Implementation. Richard D. Irwin Inc.

Porter, M. (1998). Competitive Strategy. Boston: The Free Press.

Porter, M. E. (1983). Cases in competitive strategy. Simon and Schuster.

Porter, M. E. (1998). Clusters and the new economics of competition (Vol. 76, No. 6, pp. 77-90). Boston: Harvard Business Review.

Porter, M. E., \& Millar, V. E. (1985). How information gives you competitive advantage.

Potter, M. E. (1980). Competitive strategy: Techniques for analyzing industries and competitors.

Saunders, M., Lewis, P. \& Thornhill, A. (2009). Research Methods for Business Students. 4th ed. Pearson Education Publishers. USA.

Scholes, K., Johnson, G., \& Whittington, R. (2012). Exploring corporate strategy. Financial Times Prentice Hall. 
International Journal of Business Management, Entrepreneurship and Innovation, Volume 3, Issue 1, 2021, PP 17-35 ISSN 2707-8027

\section{[IJCAB}

Shafiwu, A. B., \& Mohammed, A. (2013). The Effect of Product Differentiation on Profitability in the Petroleum Industry of Ghana. European Journal of Business and Innovation Research, 1(4), 49-65.

Sifuna, I. N. (2014). Effect of competitive strategies on performance of public universities in Kenya. Unpublished thesis Kenyatta University.

Slater, S., \& Narver, J. (1994). Does competitive environment moderate the market orientationperformance relationship? Journal of marketing, 58, 46-55.

Statements, F. L. (2016). Devonian Health Group Inc. Boston, USA: EvaluatePharma.

Tavakol, M., \& Dennick, R. (2011). Making sense of Cronbach's alpha. International journal of medical education, 2, 53.

Terfa, A., Ereso, T., Kebede, M. K. D., Rajendran, M. M. A., \& Nedelea, A. M. (2017). Assessment of the effect of Value Added Tax on consumption behavior: The Case of Nekemte Town, Wollega. Ecoforum Journal, 6(1).

Zott, C. (2013). Dynamic capabilities and the emergence of intraindustry differential firm performance: insights from a simulation study. Strategic management journal, 24(2), 97125.

This is an open-access article published and distributed under the terms and conditions of

the Creative Commons Attribution 4.0 International License of United States unless otherwise stated. Access, citation and distribution of this article is allowed with full recognition of the authors and the source. Authors seeking to publish with an Internationally Peer Reviewed Journals should consider https://www.ijcab.org/ by writing to the Editor at editor@ijcab.org or submitting online at https://journals.ijcab.org/journals/index.php. The articles must be quality and meet originality test. 